\title{
ISOLATION, CHARACTERISATION, AND SELECTION OF WINE YEAST STRAINS IN ETYEK-BUDA WINE DISTRICT, HUNGARY
}

\author{
O. Csernus ${ }^{a *}$, A. Pomázi ${ }^{\mathrm{b}}$ and I. Magyar ${ }^{\mathrm{c}}$ \\ ${ }^{\mathrm{a} U n i t}$ of Microbiology, Central Environmental and Food Science Research Institute, H-1022 Budapest, \\ Herman Ottó út 15. Hungary \\ ${ }^{b}$ Department of Microbiology and Biotechnology, Faculty of Food Science, Corvinus University of Budapest, \\ H-1118 Budapest, Somlói út 14-16. Hungary \\ ${ }^{c}$ Department of Oenology, Faculty of Food Science, Corvinus University of Budapest, H-1118 Budapest, \\ Somlói út 14-16. Hungary
}

(Received: 9 September 2013; accepted: 26 November 2013)

\begin{abstract}
Initiated by the Association "Wine Route of Etyek Wine District", the objectives of this study were to isolate and identify autochthonous yeast strains from local wines and to determine their oenologically important properties. The first aim of this work was to characterize the taxonomic and phenotypic diversity of the representative Saccharomyces yeast strains that dominate the spontaneous fermentations in this wine district. The results obtained by molecular ribotyping (ARDRA) revealed a strong dominance of $S$. cerevisiae, but $S$. bayanus var. uvarum was also present sporadically. Some of the natural isolates exhibited high volatile acid production or poor fermentation capacity, which imply a quality risk in spontaneous fermentations. Most of the isolates, however, displayed good oenological features during lab scale fermentations. As the second aim of this work, the most promising, selected strains were further tested for oenological properties in microvinification scale and, finally, in large scale fermentations. The analytical and sensory analysis proved that selected strains, including S. bayanus var. uvarum, can be used as local starter cultures, which may contribute to the typicality of the local wines in comparison with commercial starters.
\end{abstract}

Keywords: wine yeast, S. bayanus var. uvarum, S. cerevisiae, starter culture

Etyek-Buda wine district is a traditional winegrowing region of Hungary, producing mainly dry white wines and base wines for sparkling wine making. As a common result of the soil, climate, grape varieties, and winemaking traditions, Etyek-Buda wines have typical, individual character, which is considered high value on the wine market. One of the most important factors influencing wine quality and typicality is the alcoholic fermentation, which is dominated by Saccharomyces species.

Taxonomy and nomenclature of the Saccharomyces species have undergone significant changes during the last decades (VAughan-Martini \& Martini, 1998; 2011), which is out of the scope of this paper. Saccharomyces genus has recently been split into several genera, keeping the genus name Saccharomyces only for the closely related species that formerly belonged to the sensu stricto group. Out of these species it is Saccharomyces cerevisiae and, to a far lesser extent, S. bayanus, which have practical importance in winemaking (REPLANSKY et al., 2008). Within the S. bayanus species two genetically isolated varieties: S. bayanus var. bayanus and S. bayanus var. uvarum can be distinguished (IvanNiKOvA et al., 2007). The latter species variety has been suggested to be considered a distinct biological species under the

\footnotetext{
* To whom correspondence should be addressed.

Phone/fax: +36(1)796-0449/184; e-mail: o.csernus@cfri.hu
} 
name S. uvarum (Pulvirenti et al., 2000; NGuyen \& Gaillardin, 2005; NGUYen et al., 2011), but the latest taxonomic guide on yeasts kept the name $S$. bayanus var. uvarum (KURTZMAN et al., 2011; VAUGhan-Martini \& Martini, 2011). In the present paper we follow the latter nomenclature. The cryophilic $S$. bayanus var. uvarum significantly occurs in wines fermented at low temperatures (NAUMOv et al., 2000; 2002).

The taxonomy, ecology, and phenotypic properties of the $S$. bayanus species are reviewed by SIPICZKI (2002). S. cerevisiae and S. bayanus have similar morphology and physiology, so the classical method is not acceptable for their identification. Recently, molecular methods have been suggested for differentiation of the two species and the species varieties (NGuyen \& Gaillardin, 1997; Fernandez-Espinar et al., 2006).

In the traditional wineries of the Etyek-Buda wine district the spontaneous fermentation is typical, although several producers apply commercial yeast starter cultures obtained from the international market. Like in several wine districts of the world, local wine producers would be interested in using selected autochthonous yeasts for fermentation, unifying the benefits of spontaneous and inoculated fermentations.

In a previous work several spontaneously fermented wine samples were collected from traditional cellars of the Etyek-Buda wine district and the indigenous yeasts were isolated. The isolates were taken from the middle or late fermentation stages of spontaneously fermenting wines in different traditional wineries, thus they are considered representative strains of the region. The fermenting wines were diluted and spread plated on DRBC (Merck) agar, and the different colony types were isolated and purified. The possible Saccharomyces strains were selected upon morphological (vegetative reproduction, sporulation) and physiological (assimilation of different nitrogen and carbon sources) tests (CsURGAI, 2006).

During this pre-selection procedure by traditional identification methods, we established a local culture collection of 31 individual wine yeast strains, which were likely to belong to the Saccharomyces cerevisiae or closely related species.

The objectives of the present work were to carry out a carefully designed starter strain selection for autochthonous yeast strains, which are most suitable for practical oenological application.

\subsection{Yeast strains}

\section{Materials and methods}

From the Culture Collection of Department of Oenology, Faculty of Food Science, Corvinus University of Budapest fourteen strains and three commercial starter cultures, as references, were investigated in this study (Table 1).

For molecular experiments the following type strains were used: $\mathrm{CBS}^{1} 1171^{\mathrm{T}}(S$. cerevisiae); $\mathrm{CBS}^{1} 380^{\mathrm{T}}$ (S. bayanus var. bayanus); $\mathrm{CBS}^{1} 395^{\mathrm{T}}$ (S. bayanus var. uvarum) and $\mathrm{CBS}^{1} 1538^{\mathrm{T}}$ (S. pastorianus), ( ${ }^{1} \mathrm{CBS}$ : Centraalbureau voor Schimmelcultures, Baarn, The Netherlands).

\subsection{ARDRA analysis}

The DNA isolation was carried out on the basis of the protocol published by HoFFMAN and WinSTON (1987). 
Table 1. Code and source of origin of the strains

\begin{tabular}{lll}
\hline Code of strains & Source of origin & Grape-variety \\
\hline 105 & Etyek-1 & CSFT 198 \\
106 & Etyek-1 & CSFT 198 \\
201 & Etyek-1 & Irsai Olivér \\
202 & Etyek-2 & Irsai Olivér \\
204 & Etyek-2 & Irsai Olivér \\
301 & Etyek-3 & Mixed \\
302 & Etyek-3 & Mixed \\
304 & Etyek-3 & Mixed \\
402 & Etyek-4 & Pinot Gris \\
404 & Etyek-4 & Pinot Gris \\
601 & Etyek-6 & Kékfrankos \\
602 & Etyek-6 & Kékfrankos \\
701 & Etyek-7 & Sauvignon blanc \\
704 & Etyek-7 & Sauvignon blanc \\
UVA PM & UVAFERM & commercial yeast \\
UVA 228 & ERBSLÖH & commercial yeast \\
\hline & & commercial yeast \\
\hline
\end{tabular}

For amplifying the rDNA sequences the following primer pairs were applied: NS1 (5'-GTAGTCATATGCTTGTCTC-3') and ITS4 (5'-TCCTCCGCTTATTGATATGC-3') for 18S rDNS, 5.8S rDNA and ITS regions (White et al., 1990), while NTS2-F (5'AACGGTGCT TTCTGGTAG-3') and NTS2-R (5'-TGTCTTCAACTCCTTT -3') for non-transcribed spacer 2 (NTS2) (NGuYen \& Gaillardin, 1997). In case of NS1-IT4 fragment the PCR procedure was carried out using the method described by White and co-workers (1990), while in case of NTS2 the protocol of NGUYEN and GAILLARDIN (1997) was used.

For the restriction analysis of the NS1-ITS4 sequences the amplicons were cut by HaeIII, MspI, RsaI, and ScrFI restriction enzymes, where the manufacturer's instructions were followed. The amplified NTS2 fragment was digested by AluI and RsaI (PULVIRENTI et al., 2000).

The restriction fragments were separated for $90 \mathrm{~min}$ in $1.5 \%$ agarose at $120 \mathrm{~V}$. Gels were stained with ethidium-bromide, the obtained patterns were digitalized by Gel Doc 1000 System and dendograms were edited by GelComparII (Biorad) software. 


\subsection{Lab scale fermentation}

The fermentation medium was concentrated mixed grape must, which was diluted with distilled water to a sugar content of $240 \mathrm{~g} \mathrm{l}^{-1}$. Volumes of $250 \mathrm{ml}$ must were dispensed to Erlenmeyer flasks of $300 \mathrm{ml}$, closed with dense cotton plugs, then pasteurized in an autoclave at $121^{\circ} \mathrm{C}$. Each sample was inoculated with a population of $10^{6} \mathrm{CFU} \mathrm{m}^{-1}$ and the fermentations were studied in three parallels at $20^{\circ} \mathrm{C}$. An alcohol tolerant commercial starter culture (UVA $\mathrm{PM}$ ) and the 14 strains were evaluated in comparison.

\subsection{Microvinification}

Fermentation with the selected three strains $(301 ; 404 ; 704)$ and a commercial starter culture (UVA 228) and also spontaneous fermentation (without inoculation) were carried out. The commercial strain in this experiment was chosen on the basis of its delicate aroma profile and its widespread application in the wine district. Volumes of 81 Pinot Gris must (Mátra wine district, Hungary) were dispensed to glass flasks of 101 . The inoculum was prepared in $600 \mathrm{ml}$ sterile grape must. Stationary phase cultures were used for seeding the must at a population of $10^{6} \mathrm{CFU} \mathrm{ml}{ }^{-1}$. Each strain was evaluated in three parallel fermentations. After decanting and adding $75 \mathrm{mg} \mathrm{l}^{-1}$ sulphite, the experiment was evaluated by analytical methods.

\subsection{Large-scale fermentation}

In a large-scale fermentation Sauvignon blanc grape juice was used at the cellar of Hernyák Winery, Etyek-Buda wine district. Three selected strains $(105 ; 404 ; 704)$ and the commercial yeast (Erbslöh Oenoferm Freddo), generally applied by this winery, were used. The inoculum was prepared in several steps until the population reached $10^{6} \mathrm{CFU} \mathrm{ml}^{-1}$ of 201 must. The dynamics of fermentation was monitored at $18{ }^{\circ} \mathrm{C}$ in a $10 \mathrm{hl}$ steel container. Due to the volume of the experiment, there was no possibility to set replicates.

\subsection{Analytical studies}

Fermentation dynamics was monitored by measuring the sugar content with ATAGO RX5000 digital refractometer. The wines were analysed for chemical composition: alcohol, volatile acid, residual sugar, acetaldehyde, and sulphite, using official methods of wine analysis (OIV, 2013). Glycerol was evaluated by enzymatic method (Boeringer enzyme test). Acetaldehyde was determined by photometric method (REBELEIN, 1970).

\subsection{Sensory analysis}

The young experimental wines were evaluated by sensory analysis. Samples of microvinification were blind tasted by six wine professionals. The colour, odour, flavour, and complexity of the wines were evaluated on a 5-point scale.

Wines of large-scale fermentation were tested by quantitative descriptive analysis (profile analysis). Seven wine professionals participated in the organoleptic analysis, and ten features of the wines had to be marked on an unstructured scale. 


\subsection{Statistical analysis}

Data from analytical and sensory analysis were statistically evaluated by single factor analysis of variance, using the statistical software SPSS 14.0 for Windows. The factor was represented by the yeast strains, the repetitions were the data from repeated fermentations. When the ANOVA determined significant effect of species at a level $\mathrm{P}<0.05$, LSD values were calculated to determine, which pairs of means differ.

\section{Results and discussion}

\subsection{Identification of the yeast strains by ARDRA analysis}

The pre-identified Saccharomyces strains were identified by PCR-based ARDRA method to separate $S$. cerevisiae and other possible Saccharomyces species. Of the 14 Saccharomyces strains tested for oenological properties, 4 strains were excluded upon disadvantageous oenological traits (see section 2.2).

As a result of the NS1-ITS4 rDNA restriction analysis all isolates were identified. Strain 105 belonged to the cluster with the type strains of $S$. bayanus var. bayanus and S. bayanus var. uvarum, the other isolates were identified as $S$. cerevisiae (Fig. 1).

ARDRA+ARDRA_1+ARDRA_2

NS1

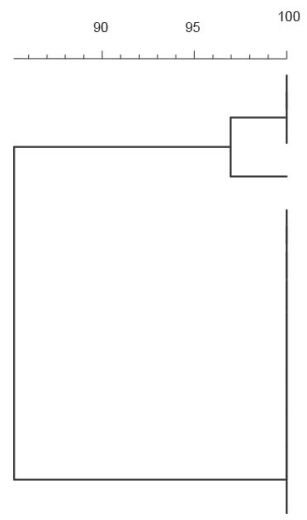

NS1

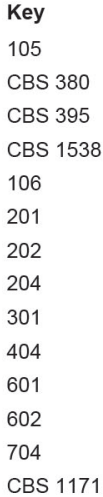

Genus

Saccharomyces

Saccharomyces

Saccharomyces
Species

bayanus var. bayanus bayanus var. uvarum pastorianus

Fig. 1. The NS1 - ITS4 sequence-based dendogram of isolates and type strains. All isolates except for one strain (105) have been identified as S. cerevisiae

In order to identify the S. bayanus varieties, in the case of strain 105, NTS2 sequence analysis was also performed (PulvirentI et al., 2000). On the basis of the restriction patterns obtained by RsaI and AluI, the strain 105 has been identified as S. bayanus var. uvarum (Fig. 2). 


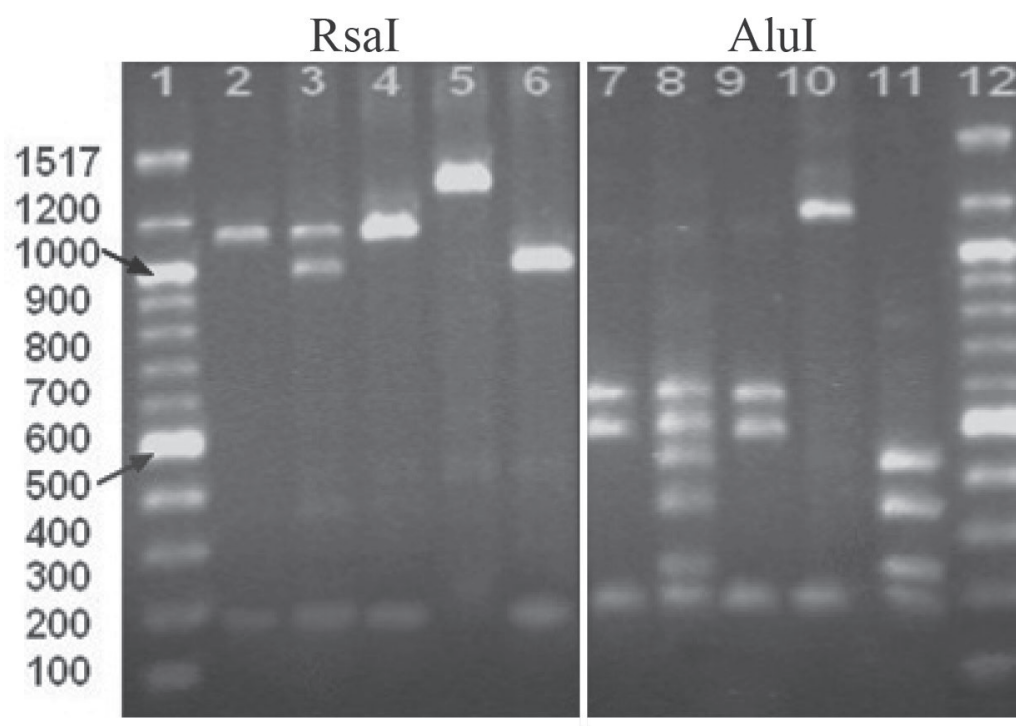

Fig. 2. NTS2 sequence restriction analysis. RsaI patterns: 1. Marker 2. isolate 105 3. CBS $380^{\mathrm{T}}$ (S. bayanus var.

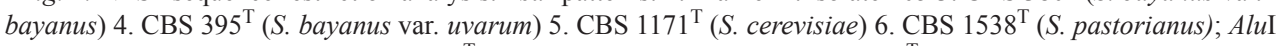

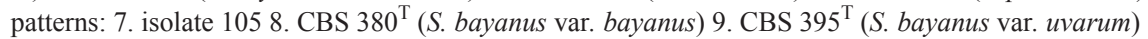
10. CBS $1171^{\mathrm{T}}$ (S. cerevisiae) $11 . \mathrm{CBS} 1538^{\mathrm{T}}$ (S. pastorianus) 12. Marker

This species is common in certain wine districts, particularly where sweet wines are produced and the fermentation temperature is typically low (SIPICZKI, 2002), but it is considered a "rare" wine yeast in the majority of winegrowing regions. Recently more and more $S$. bayanus var. uvarum strains isolated from wine environment have been identified (reviewed by NAUMOV et al., 2011).

The diversity of Saccharomyces populations in Tokaj wine district has been thoroughly investigated (SiPICZKI et al., 2001; NAumov et al., 2002; Antunovics et al., 2003; 2005; MAGYAR et al., 2008), and S. bayanus var. uvarum was found a regular and important contributor to wine fermentations. Saccharomyces biota of other wine districts of Hungary were studied sporadically (SzüCS et al., 2005; Csoma et al., 2010), and a low presence of $S$. bayanus var. uvarum was detected. Our results show that this species is present in the autochthonous yeast biota of Etyek-Buda wine district as well.

\subsection{Lab scale fermentation}

Since the high alcohol tolerance is a general requirement in wine yeast strain selection, we set a higher than typical sugar content $\left(240 \mathrm{~g} \mathrm{l}^{-1}\right)$ in the grape juice. Within the examination period none of the strains utilized the high sugar content completely, but there were significant differences in the residual sugar concentrations. The fermentation dynamics of the isolates varied from poor to very good - comparable with the excellent fermenting commercial starter. Some typical examples for fermentation curves are shown in Fig. 3. 
A

105

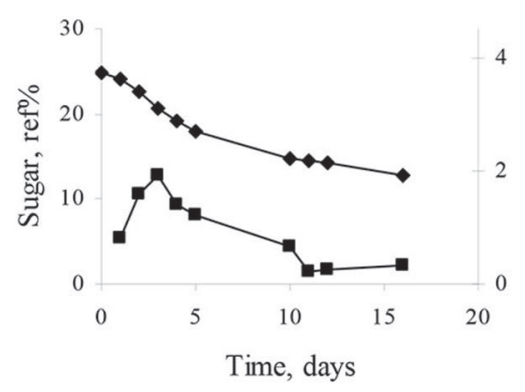

$\mathrm{C}$

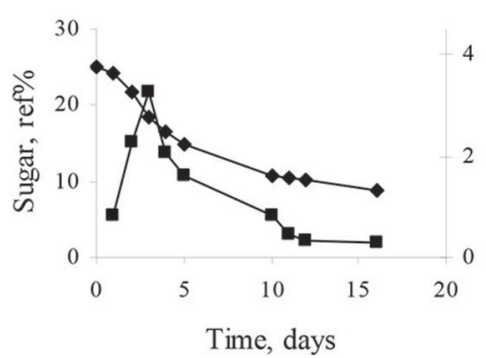

B

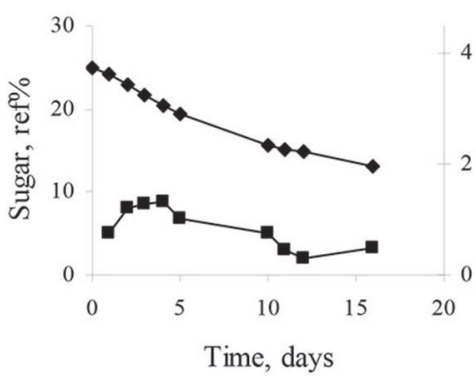

UVA PM

$\mathrm{D}$

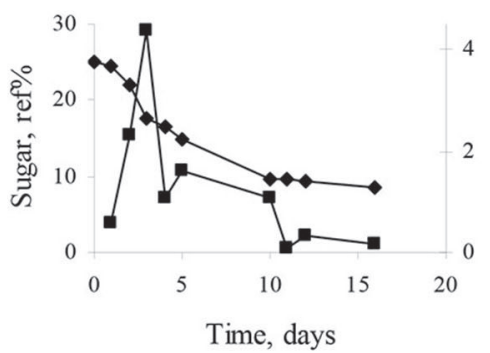

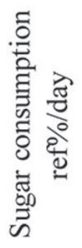

Fig. 3. Examples for fermentation dynamics in high sugar content grape juice. Local S. b. var. uvarum (A), S. cerevisiae strains (B-C) and commercial starter culture (D). Evolution of sugar concentration (diamonds) and the rate of sugar consumption (squares)

Metabolic products of yeasts have vital importance in the oenological evaluation of the different strains (Table 2).

Beside the capability of dynamic fermentation, the low production of volatile acidity was the main selection criteria. A low sulphite production of the strains was also a critical aspect for the selection. Three isolates (106; 602 and UVA PM commercial starter) produced significantly higher sulphite content than the other yeast strains. In accordance with this, the concentrations of acetaldehyde for the same isolates were significantly higher than for the other strains, as well. This property is disadvantageous in oenology because of the strong capacity of acetaldehyde for binding sulphite.

Considering the fermentation dynamics and by-products together, three strains (301; $404 ; 704)$ were selected for further investigations on microvinification scale. Although the S. bayanus var. uvarum strain no. 105 (further on S. bayanus 105) performed slow and incomplete fermentation in this series, later we included it into the large scale experiment because of its expectable interesting oenological properties known from the literature (eg.cryophylic character, high glycerol and low acetic acid production, special aroma production). 
Table 2. Fermentation profile of local Saccharomyces isolates and a commercial starter (Uvaferm PM) in laboratory scale fermentation

\begin{tabular}{|c|c|c|c|c|c|c|c|}
\hline Strains & $\begin{array}{c}\text { Alcohol } \\
\text { v/v\% }\end{array}$ & $\begin{array}{l}\text { Residual } \\
\text { sugar } \\
\mathrm{g} \mathrm{l}^{-1}\end{array}$ & $\begin{array}{c}\text { Total } \\
\text { acidity } \\
\mathrm{g} \mathrm{l}^{-1}\end{array}$ & $\begin{array}{l}\text { Volatile } \\
\text { acidity } \\
\mathrm{g} \mathrm{l}^{-1}\end{array}$ & $\begin{array}{l}\text { Acetalde- } \\
\text { hyde } \\
\mathrm{mg} \mathrm{l}^{-1}\end{array}$ & $\begin{array}{c}\text { Glycerol } \\
\mathrm{g} \mathrm{l}^{-1}\end{array}$ & $\begin{array}{c}\text { Total SO2 } \\
\mathrm{mg} \mathrm{l}^{-1}\end{array}$ \\
\hline 105 & 10.93 & 49.50 & 6.25 & 0.91 & 9.70 & 4.96 & 26.00 \\
\hline 106 & 14.17 & 28.95 & 6.45 & 0.89 & 29.40 & 6.16 & 64.00 \\
\hline 201 & 13.70 & 15.45 & 6.85 & 0.98 & 7.20 & 7.27 & 16.00 \\
\hline 202 & 13.86 & 18.30 & 6.85 & 0.99 & 5.40 & 6.40 & 16.00 \\
\hline 204 & 10.80 & 72.60 & 6.60 & 1.11 & 9.30 & 5.44 & 24.00 \\
\hline 301 & 14.11 & 11.50 & 6.90 & 0.91 & 4.90 & 6.54 & 21.00 \\
\hline 302 & 13.70 & 23.55 & 6.95 & 1.07 & 3.50 & 7.50 & 21.00 \\
\hline 304 & 12.55 & 37.50 & 6.85 & 1.04 & 3.00 & 7.19 & 21.00 \\
\hline 402 & 14.17 & 7.85 & 7.10 & 1.07 & 7.90 & 7.31 & 18.00 \\
\hline 404 & 14.23 & 9.90 & 6.80 & 0.76 & 7.50 & 6.42 & 23.00 \\
\hline 601 & 13.65 & 21.60 & 7.05 & 0.96 & 0.00 & 5.44 & 13.50 \\
\hline 602 & 13.67 & 12.85 & 7.05 & 1.04 & 30.10 & 6.43 & 61.00 \\
\hline 701 & 9.68 & 86.90 & 6.05 & 0.43 & 5.40 & 5.19 & 21.00 \\
\hline 704 & 14.12 & 11.30 & 6.90 & 0.80 & 4.70 & 6.83 & 21.00 \\
\hline UVA PM & 14.30 & 8.80 & 6.05 & 0.82 & 46.50 & 7.44 & 75.00 \\
\hline LSD5\% & 1.18 & 30.10 & 0.21 & 0.14 & 3.92 & 0.81 & 6.70 \\
\hline
\end{tabular}

Data are means of 3 replicate fermentations. LSD5\% means the least significant differences among strains at $\mathrm{P}>0.05$.

\subsection{Microvinification}

In the microvinification experiments a normal sugar content $\left(220 \mathrm{~g}^{-1}\right)$ fresh grape juice was used, which was completely fermented by all the strains. Considering the analytical composition of the wines, all three strains $(301 ; 404 ; 704)$ proved appropriate for fermentation of high quality white wine (data not shown).

The main goal of this experiment was to evaluate the aroma production of the strains. For this reason, a particularly delicate aroma producer starter culture (Uvaferm 228) was used as reference strain. During sensory analysis, two of the local strains were evaluated superior to the commercial starter culture (Fig. 4). 


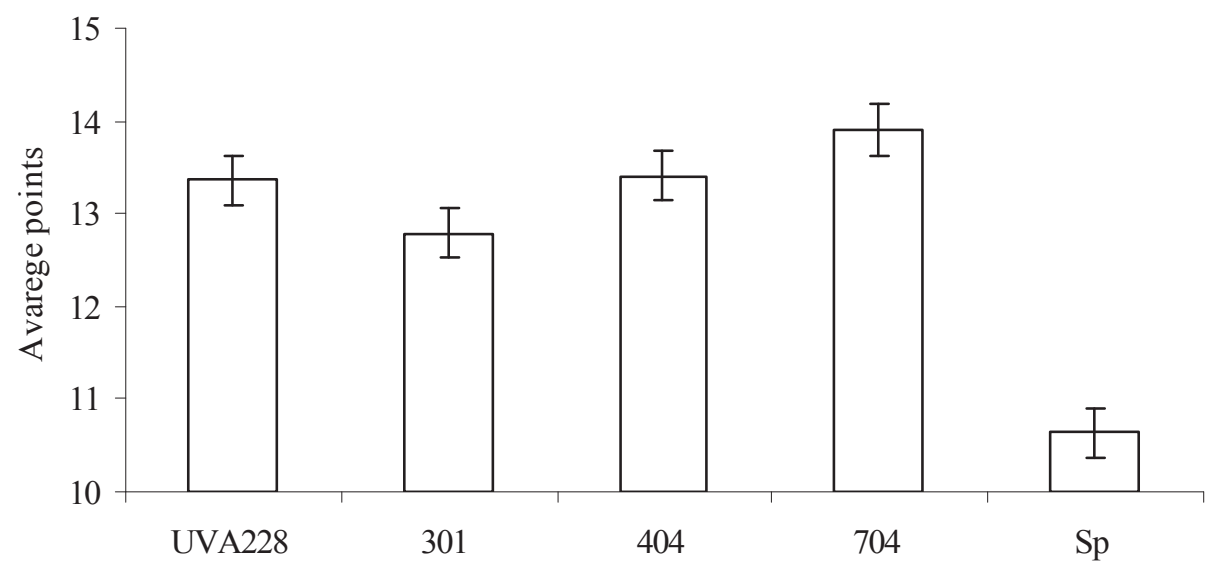

Fig. 4. Results of sensory analysis at the microvinification experiment. Columns are average points of three parallels $\times$ six wine professionals, bars are LSD values at $\mathrm{P}=0.05)(\mathrm{Sp}-$ spontaneous fermentation (without inoculation))

\subsection{Large-scale fermentation}

Large-scale fermentation was carried out with the two best $S$. cerevisiae $(404 ; 704)$ and the S. bayanus (105) strains. In accordance with the literature data (e.g. GIUDICI et al., 1995; MASNeUf-Pomarede et al., 2010), S. bayanus produced significantly more glycerol and less volatile acidity than $S$. cerevisiae strains (Table 3 ).

Table 3. Analytical results of the wines fermented by three selected strains $(105 ; 404 ; 704)$ and a commercial starter culture (Freddo) on large scale

\begin{tabular}{|c|c|c|c|c|c|c|c|c|}
\hline Strains & $\begin{array}{l}\text { Alcohol } \\
\text { v/v \% }\end{array}$ & $\begin{array}{l}\text { Rre- } \\
\text { sidual } \\
\text { sugar } \\
\mathrm{g} \mathrm{l}^{-1}\end{array}$ & $\begin{array}{c}\text { Total } \\
\text { acidity } \\
\mathrm{g} \mathrm{l}^{-1}\end{array}$ & $\begin{array}{l}\text { Volatile } \\
\text { acidity } \\
\mathrm{g} \mathrm{l}^{-1}\end{array}$ & $\begin{array}{l}\text { Acetal- } \\
\text { dehyde } \\
\mathrm{mg} \mathrm{l}^{-1}\end{array}$ & $\begin{array}{l}\text { Total } \\
\mathrm{SO}_{2} \\
\mathrm{mg} \mathrm{l}^{-1}\end{array}$ & $\begin{array}{c}\text { Glycerol } \\
\mathrm{g} \mathrm{l}^{-1}\end{array}$ & $\begin{array}{c}\text { Extract } \\
\mathrm{g} \mathrm{l}^{-1}\end{array}$ \\
\hline S. bayanus 105 & 12.61 & 2.40 & 7.50 & 0.31 & 21.60 & 45 & 9.3 & 24.0 \\
\hline S. cerevisiae 404 & 12.70 & 1.00 & 8.50 & 0.40 & 19.80 & 32 & 6.0 & 21.6 \\
\hline S. cerevisiae 704 & 13.05 & 3.30 & 8.00 & 0.37 & 21.90 & 40 & 4.7 & 23.2 \\
\hline $\begin{array}{l}\text { Freddo (starter } \\
\text { culture) }\end{array}$ & 12.96 & 1.20 & 8.50 & 0.33 & 16.80 & 43 & 7.8 & 21.4 \\
\hline
\end{tabular}


As a result of the sensory analysis each wine received good ratings. The sensory profile of $S$. bayanus showed different aroma characteristics in comparison with the local $S$. cerevisiae strains and a commercial starter culture (Freddo). The distinct odour produced by $S$. bayanus was differently evaluated by the judges; two evaluations were significantly different. The majority of them found this characteristic aroma delicate (Fig. 5).

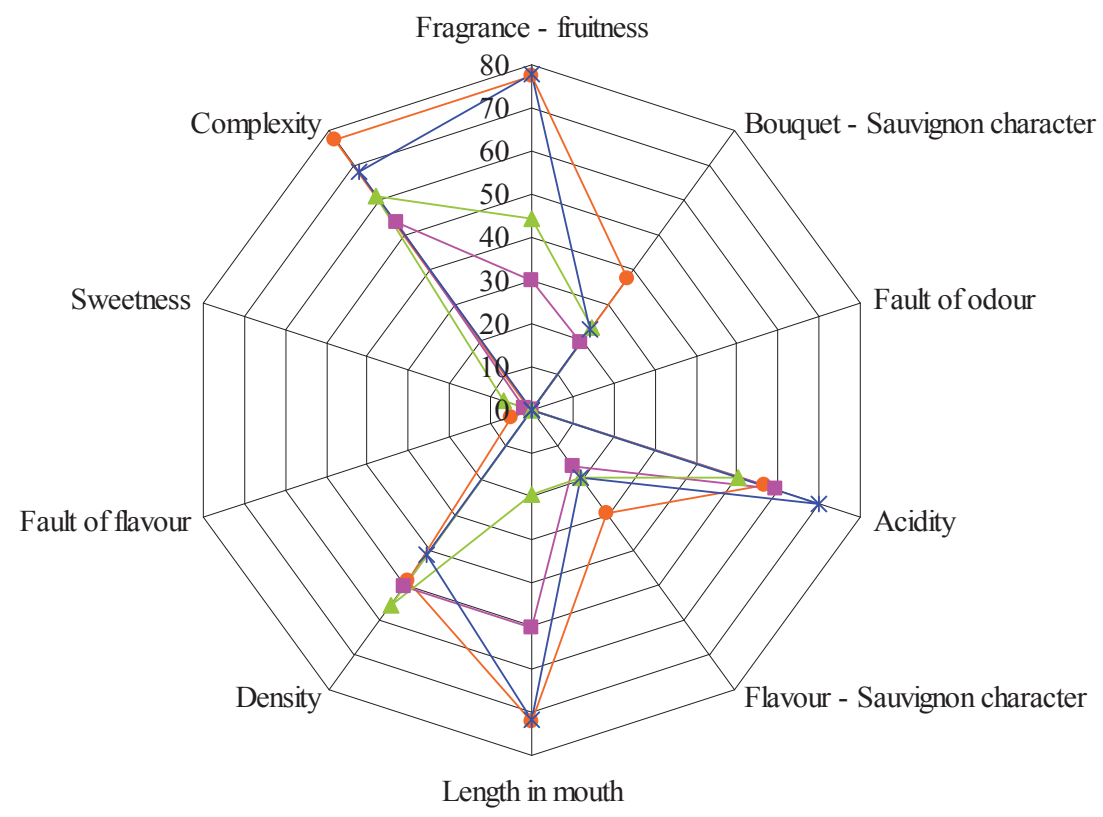

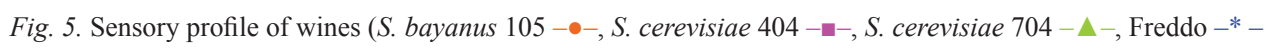
(starter culture)) evaluated by five wine professionals

S. bayanus 105 gave the best overall impression, and the reason was the special odour of the wine, which increased the character of Sauvignon blanc. The special aroma character may arise from a high 2-phenylethyl alcohol production of the S. bayanus (MAssoutier et al., 1998; ANTONELLI et al., 1999).

\section{Conclusions}

In the autochthonous microbiota of Etyek wines $S$. bayanus var. uvarum is present along with $S$. cerevisiae. Some of the natural isolates of $S$. cerevisiae exhibited high volatile acid production or poor fermentation capacity, which imply a quality risk in spontaneous fermentations. The autochthonous yeast strains selected during this work may be used as starter cultures in controlled fermentations of local wines without loosing the typical character of the terroir. On the basis of the results we found the $S$. bayanus var. uvarum 105 strain the best candidate as local starter culture, but also the chosen $S$. cerevisiae strains can be considered for practical application in fermentations of Etyek-Buda wines. 
The authors would like to thank student B. Csurgai for the isolation of the yeast strains and Hernyák Winery for organizing and hosting the large scale experiments.

\section{References}

Antonelli, A., Castellari, L., Zambonelli, C. \& Carnacini, A. (1999): Yeast influence on volatile composition of wines. J. Agric. Fd Chem., 47, 1139-1144.

Antunovics, Z., Csoma, H. \& Sipiczki, M. (2003): Molecular and genetic analysis of the yeast flora of botrytized Tokaj wines. Bull. O.I.V., 76, 380-397.

Antunovics, Z., IrinYi, L. \& SipICZKI, M. (2005): Combined application of methods to taxonomic identification of Saccharomyces strains in fermenting botrytized grape must. J. Appl. Microbiol., 98, 971-979.

Csoma, H., ZaKany, N., CAPECE, A., Romano, P. \& Sipiczki, M. (2010): Biological diversity of Saccharomyces yeasts of spontaneously fermenting wines in four wine regions: Comparative genotypic and phenotypic analysis. Int. J. Fd Microbiol., 140, 239-248.

Csurgai, B. (2006): Borélesztö törzsek izolálása és elöszelektálása borászati célra az Etyeki borvidéken. (Isolation and selection of local wine yeast strains from Etyek wine district) Thesis. Corvinus University of Budapest, p. 32.

Fernandez-Espinar, M.T., Martorell, P., de Llanos, R. \& Querol, A. (2006): Molecular methods to identify and characterise yeasts in foods and beverages. -in: Querol, A. \& FleEt, G.H. (Eds.) Yeasts in food and beverages. Springer, Berlin-Heidelberg, Germany, pp. 55-82.

Giudici, P., Zambonelli, C., Passarelli, P. \& Castellari, L. (1995): Improvement of wine composition with cryotolerant Saccharomyces species. Am. J. Enol. Vitic., 46, 143-147.

Hoffman, C.S. \& Winston, F. (1987): A ten-minute preparation from yeast efficiently releases autonomous plasmids for transformation of Escherichia coli. Gene, 57, 267-272.

Ivannikova, Y.V., Naumova, E.S. \& Naumov, G.I. (2007): Viral dsRNA in the wine yeast Saccharomyces bayanus var. uvarum. Res. Microbiol., 158, 638-643.

Kurtzman, C.P., Fell, J.W. \& Boekhout, T. (Eds) (2011): The yeasts, a taxonomic study. 5th ed. Elsevier, London, 2354 pages.

Magyar, I., Tóth, T. \& PomÁzi, A. (2008): Oenological characterization of indigenous yeasts involved in fermentation of Tokaji aszú. Bull. O.I.V., 81, 35-43.

Masneuf-Pomarède, I., Bely, M., Marullo, P., Lonvaud-Funel, A. \& Dubourdieu, D. (2010): Reassessment of phenotypic traits for Saccharomyces bayanus var. uvarum wine yeast strains. Int. J. Fd Microbiol., 139, 7986.

Massoutier, C., Alexandre, H., Feuillat, M. \& Charpentier, C. (1998): Isolation and characterization of cryotolerant Saccharomyces strains. Vitis, 37, 55-59.

Naumov, G.I., Masneuf, I., Naumova, E.S., Aigle, M. \& Dubourdieu, D. (2000): Association of Saccharomyces bayanus var. uvarum with some French wines: genetic analysis of yeast population. Res. Microbiol., 151, 683-691.

Naumov, G.I., Naumova, E.S., Antunovics, A. \& Sipiczki, M. (2002): Saccharomyces bayanus var. uvarum in Tokaj wine-making of Slovakia and Hungary. Appl. Microbiol. Biotechnol., 59, 727-730.

Naumov, G.I., Naumova, E.S., Martynenko, N.N. \& Masneuf-Pomaréde, I. (2011): Taxonomy, ecology, and genetics of the yeast Saccharomyces bayanus: A new object for science and practice. Microbiol., 80, 735-742.

Nguyen, H-V. \& Gaillardin, C. (1997): Two subgroups within the Saccharomyces bayanus species evidenced by PCR amplification and restriction polymorphism of the non-transcribed spacer 2 in the ribosomal DNA unit. System. Appl. Microbiol., 20, 286-294.

Nguyen, H-V. \& Gaillardin, C. (2005): Evolutionary relationships between the former species Saccharomyces uvarum and the hybrids Saccharomyces bayanus and Saccharomyces pastorianus; reinstatement of Saccharomyces uvarum (Beijerinck) as a distinct species. FEMS Yeast Res., 5, 471-483.

Nguyen, H-V., Legras, J-L., Neuvéglise, C. \& Gaillardin, C. (2011): Deciphering the hybridisation history leading to the lager lineage based on the mosaic genomes of Saccharomyces bayanus strains NBRC1948 and CBS380 ${ }^{\mathrm{T}}$. PLoS ONE 6 (10): e25821. doi:10.1371/journal.pone.0025821

OIV (2013): International methods of analysis of wines and musts. http://www.oiv.int/oiv/info/enmethodesinternati onalesvin\#alcools 
Pulvirenti, A., Nguyen, HV., Caggia, C., Giudicci, P., Rainieri, S. \& Zambonelli, C. (2000): Saccharomyces uvarum, a proper species within Saccharomyces sensu stricto. FEMS Microbiol. Lett., 192,191-196.

ReBelein, H. (1970): Beitrag zur Bestimmung und Beurteilung des Azetaldehydes bzw. der Azetaldahyd gebundenen Schweflingen Saure im Wein. Dtsch Lebensm. - Rundsch. 66, 6-11.

Replansky, T., Koufopanou, V., Greig, D. \& Bell, G. (2008): Saccharomyces sensu stricto as a model system for evolution and ecology. Trends Ecol. Evol., 23, 494-501.

Sipiczki, M., Romano, P., Lipani, G., Miklos, I. \& Antunovics, Z. (2001): Analysis of yeasts derived from natural fermentation in a Tokaj winery. Antonie van Leeuwenhoek, 79, 97-105.

SiPICZKI, M. (2002): Taxonomic and physiological diversity of Saccharomyces bayanus. -in: Ciani, M. (Ed.) Biodiversity and biotechnology of wine yeasts. Research Signpost, Kerala, pp. 53-69.

SzŰCs, E., LeHoczKi-Tornai, J. \& PÉTER, G. (2005): Élesztőszelekció az egri vörösborok egyediségének biztosítása érdekében. (Yeast selection to ensure the uniqueness of red wines in Eger) Lippay János-Ormos Imre-Vas Károly Scientific Symposium, October 19-20, Budapest, Supplement. pp. 178-179.

Vaughan-Martini, A. \& Martini, A. (1998): Saccharomyces Meyen ex Rees. -in: Kurtzman, C.P. \& Fell, J.W. (Eds) The yeasts, a taxonomic study. Elsevier Science Publishers, Amsterdam, pp. 358-371.

Vaughan-Martini, A. \& Martini, A. (2011): Saccharomyces Meyen ex Rees. -in: Kurtzman, C.P., Fell, J.W. \& Boekhout, T. (Eds) The yeasts, a taxonomic study. Elsevier Science Publishers, Amsterdam, pp. 733-746.

White, T.J., Bruns, T., LeE, S. \& TAYlor, J. (1990): Amplification and direct sequencing of fungal ribosomal rna genes for phylogenetics. -in: InNis, M.A., Gelfand, D.H., Sninsky, J.J. \& White, T.J. (Eds) PCR protocols: A guide to methods and applications, Academic Press, pp. 315-321. 